\title{
Analisis Kapasitas Lentur Balok Beton Tulang Berongga Akibat Perbedaan Kuat Tarik Tulangan
}

\author{
Analysis of the Bending Capacity of Hollow Bone Concrete Beams Due to Differences in \\ Tensile Strength of Reinforcements
}

\author{
Syahrul Sariman ${ }^{1 *}$, Rita Irmawaty ${ }^{2}$ \\ "Email: syahrul.sariman@universitasbosowa.ac.id \\ ${ }^{1}$ Program Studi Teknik Sipil Fakultas Teknik Universitas Bosowa \\ ${ }^{1}$ Departemen Teknik Sipil Fakultas Teknik Universitas Hasanuddin \\ Diterima: 17 September 2021 / Disetujui: 24 Desember 2021
}

\begin{abstract}
ABSTRAK
Penelitian ini bertujuan menetapkan karakteristik lentur balok beton tulang berongga akibat perbedaan kuat tarik tulangan. Dalam penelitian ini digunakan balok beton bertulang dengan mutu beton $\mathrm{f}^{\prime} \mathrm{c}=27 \mathrm{Mpa}$ dan dimensi $150 \times 350 \mathrm{~mm}$, Panjang 3300mm dengan tulangan pokok 3D16mm dengan kuat leleh fy=475 Mpa (type WS) dan fy=324MPa (type RM). Setiap balok dengan type tulangan yang berbeda terdiri dari 3 balok yang dibedakan menurut panjang rongganya dan diberi notasi BR3A, BR3B dan BR3C. dengan tinggi rongga tetap : $180 \mathrm{~mm}$. Hasil penelitian menunjukkan bahwa variasi rongga tidak mempengaruhi kapasitas setiap balok dalam memikul momen. Perbedaan kapasitas momen lentur disebabkan oleh perbedaan kuat tarik baja tulangan.
\end{abstract}

Kata Kunci: Kuat Tarik Baja Tulangan, Beton Bertulang, Rongga Botol Plastik

\section{ABSTRACT}

This study aims to determine the flexural characteristics of hollow reinforced concrete beams due to differences in the tensile strength of reinforcement. In this study used reinforced concrete beams $f^{\prime} \mathrm{c}=26.85 \mathrm{MPa}$ and dimensions $150 \times 350 \mathrm{~mm}$, length $3300 \mathrm{~mm}$. Bar reinforcement of 3Dl6mm with $f y=475 \mathrm{Mpa}$ (WStype) and fy=324MPa (RMtype). Each beam with a different type of reinforcement consists of 3 beams that are distinguished by the length of the hollow which is namely BR3A, BR3B and BR3C. with a fixed hollow height $(180 \mathrm{~mm})$. The results showed that hollows variations did not affect the carrying capacity of the moment. Different of capacity bending moment is caused by the difference in the tensile strength of the reinforcement.

Keywords: Tensile Strength of Reinforcement, Reinforced Concrete, Plastic Bottle Hollows

(c) ()

\section{A. PENDAHULUAN}

Dasar pemikiran timbulnya struktur balok beton bertulang berongga diawali dengan perilaku struktur balok bertulang dalam memikul beban lentur. Akibat momen lentur serat atas akan tertekan dan serat bawah akan tertarik. Dalam kondisi seimbang, kekuatan tarik yang dipikul oleh baja tulangan dibuat sama dengan kekuatan tekan yang dipikul oleh penampang beton diatas garis netral, dengan demikian ada bagian beton dibawah garis netral yang tidak diperhitungkan memikul gaya tekan, sehingga bagian tersebut dapat dihilangkan atau dibuat berlobang. Illustrasi mengenai 
mekanisme kerja balok beton bertulang dapat dilihat pada Gambar 1
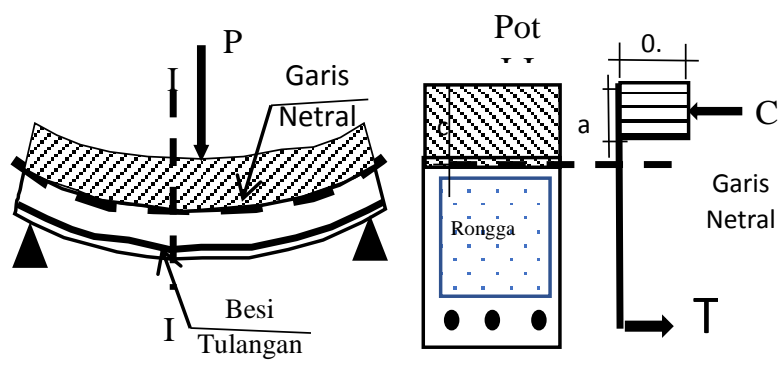

Gambar 1. Balok Beton Bertulang Yang Memikul Beban Lentur

Tujuan pemberian rongga pada balok beton bertulang adalah agar struktur menjadi lebih ringan, mereduksi produksi semen sebagai material dasar pembuatan beton, menyiapkan tempat untuk fasilitas utilitas dan dapat dimanfaatkan untuk penampungan limbah. Beberapa penelitian telah dilakukan berkaitan dengan balok beton bertulang berongga antara lain dengan menggunakan pipa PVC, seperti yang dilakukan oleh Jain Joy, et al (2014), , Aswathy S Kumar, et al (2015), Anju Varghese, et al (2016), Nibin Varghese et al (2016), Dhinesh.N.P, et al (2017) dan N Parthiban, et al (2017). Penelitian P. Sivaneshan, 2017, memanfaatkan bola Polythene daur ulang plastik, kemudian dimasukkan dalam campuran beton.

Bentuk lain dari pemanfaatan limbah produk plastik adalah dengan menempatkannya sebagai pembentuk rongga seperti pada penelitian Rahadyanto (2013). dengan tujuan khusus bagaimana menempatkan botol pada saat pengecoran beton karena adanya sifat mengambang pada botol akibat tekanan keatas dari beton yang baru dicor, Penelitian dilakukan dengan menggunakan balok beton berongga botol plastic dengan mutu beton yang berbeda (K300 dan K400). Hasil test menunjukkan bahwa tidak ada pengaruh rongga dan mutu beton terhadap kapasitas lentur balok uji.

Penelitian lainnya yang menyangkut pemanfaatan botol plastik sebagai pembentuk rongga pada balok, dilakukan oleh Mathew, I et al (2016) dengan menempatkan rangkaian botol plastik pada garis netral balok (NOB)), dibawah garis netral (N10B0), dan sekaligus dibawah garis netral dan pada garis netral (N10B10).

Tegangan tarik akibat beban yang timbul pada struktur beton bertulang sepenuhnya dipikul oleh tulangan baja. Dalam memikul tegangan tarik ada 4 daerah yang dibentuk dari hubungan tegangan regangan yang diperoleh dari pengujian tarik yakni a). daerah elastis, b). daerah plastis $\mathrm{c})$. daerah strain hardening dan d) daerah necking. Karakteristik tulangan baja hasil uji Tarik yang dinyatakan dqlqm hubungqn tegangan regangan dapat dilihat pada gambar 2

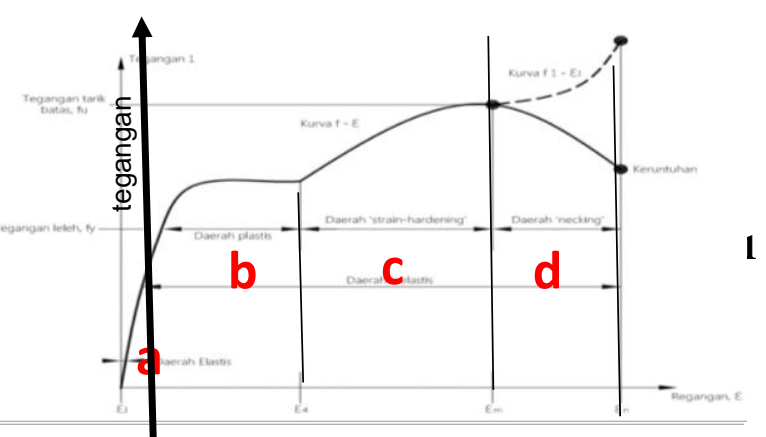


Menurut Park \& Paulay (1933), apabila beban bekerja pada balok maka kondisi seimbang antara tegangan regangan akan lenyap dan diagram tegangan tekan pada penampang balok

regangan

Gambar 2. Diagram Regangan dan Tegangan Hasil Uji Tarik Baja

Daerah elastis dimulai dari titik $\mathrm{O}$ sampai batas proporsional, yang merupakan kurva linier dengan peningkatan regangan berbanding lurus dengan kenaikan tegangan. Selanjutnya daerah plastis dari batas proporsional ( titik leleh ) ditandai dengan adanya peningkatan regangan tanpa adanya peningkatan tegangan yang berarti. Menurut Nasution, A (2009), Kelelehan terjadi karena adanya pergeseran internal pada material baja ditingkat atom. Selanjutnya daerah "strain hardening" ditandai dengan adanya peningkatan tegangan seiring dengan pertambahan regangan sampai kurva mencapai puncak, yang diakibatkan oleh berkurangnya luas penampang spesimen pada titik tertentu. Tegangan maksimum pada kurva disebut tegangan tarik batas atau kuat batas (ultimate strength). Selanjutnya memasuki daerah "Necking" yang diawali dari puncak kurva yang selanjutnya terjadi pertambahan regangan namun tegangan berkurang sampai akhirnya material putus. beton akan berbentuk setara dengan kurva tegangan - regangan tekan seperti terlihat pada gambar 3 :

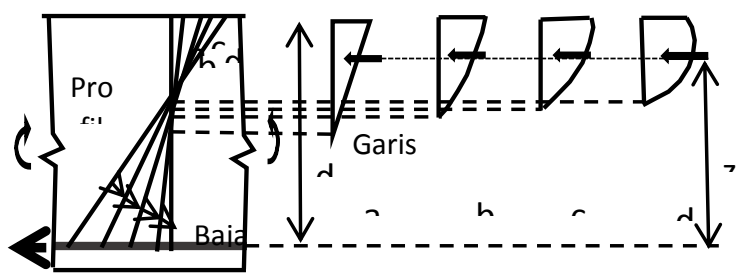

Gambar 3. Diagram Regangan Dan Tegangan Balok Beton Bertulang

Pada kondisi plastis tegangan beton tekan akan membentuk kurva nonlinier.

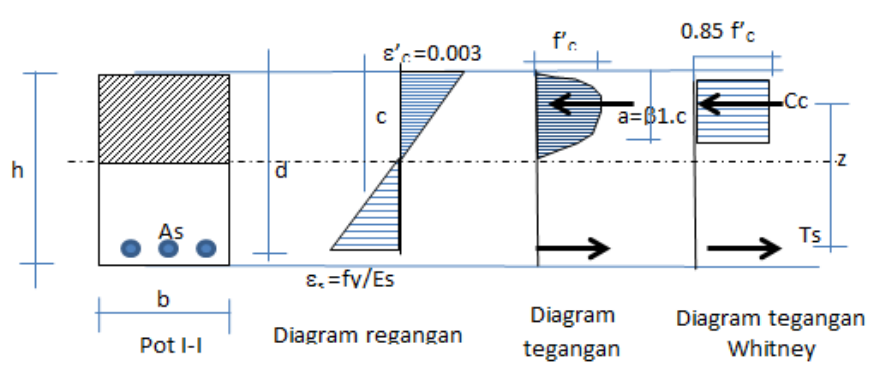

Gambar 4. Grafik Hubungan TeganganRegangan Kondisi Plastis

Besar gaya-gaya dalam :

Gaya Tekan : $\mathrm{Cc}=0,85 \mathrm{f}_{\mathrm{c}} \mathrm{b}$ a

Gaya Tarik: $\mathrm{Ts}=\mathrm{A}_{\mathrm{s}} \mathrm{f}_{\mathrm{y}}$

dan keseimbangan gaya dalam $\mathbf{C c}=\mathbf{T s}$ memberikan hasil tinggi blok tegangan : a

$$
\mathrm{a}=\frac{\mathrm{A}_{\mathrm{s}} \cdot \mathrm{f}_{\mathrm{y}}}{0.85 . \mathrm{f}_{\mathrm{c}}^{\prime} \cdot \mathrm{b} .}
$$

letak garis netral $\mathrm{c}=\mathrm{a} / \square 1$..... (4) 
Momen Nominal :

$$
\begin{aligned}
& M_{n}=C(d-a / 2) \quad \text { atau } \\
& M_{n}=T(d-a / 2)
\end{aligned}
$$

Hubungan beban-lendutan balok beton bertulang pada dasarnya dapat diidealisasikan menjadi bentuk trilinier. dan terdiri atas tiga daerah sebelum terjadinya rupture (Nawy, 1996). Hubungan beban lendutan dapat dillustrasikan sebgaimana mana gambar 3 berikut

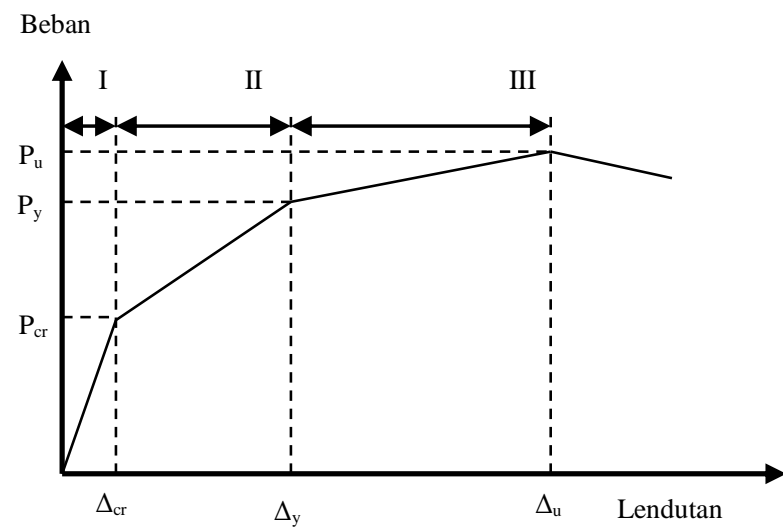

Gambar 5. Grafik Hubungan Beban dan Lendutan

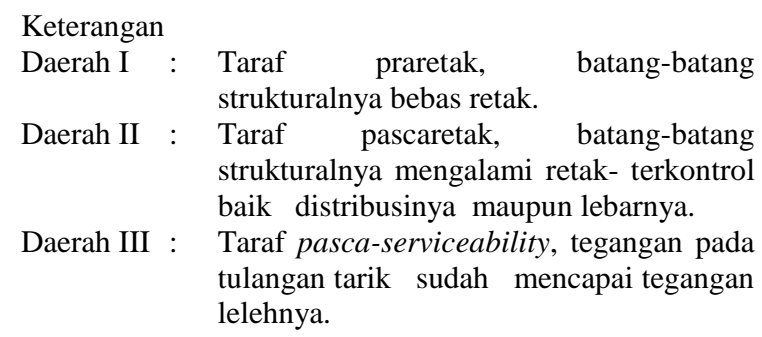

Oleh karena bervariasinya kuat Tarik tulangan yang tersedia di pasaran maka perlu dilakukan penelitian yang berkaitan dengan kuat Tarik baja tulangan tersebut. Penelitian ini melanjutkan penelitian yang dilakukan sebelumnya, khususnya mengenai perilaku lentur balok bertulang dengan botol plastik sebagai pembentuk rongga yang ditempatkan pada penampang tarik. . Untuk mengetahui pengaruh rongga terhadap kuat lentur balok beton bertulang, efektifitas rongga dan hubungan beban lendutan pada balok beton tulang berongga yang berbeda kuat Tarik tulangannya dilakukan uji lentur dengan menggunakan 2 (dua) jenis tulangan baja dengan kuat Tarik yang yang berbeda. Karakteristik tulangan yang digunakan hasil pengujian kuat Tarik dapat dilihat padaTabel 1 .

Tabel 1. Data Hasil Pengujian 2 Jenis Besi Tulangan WS dan MR

\begin{tabular}{lcc}
\hline \multicolumn{1}{c}{ Jenis Tulangan } & WS 16 SNI & RM 16 SNI \\
\hline Berat Benda Uji, kg/L mm & 0.4518 & 0.4422 \\
Diameter benda Uji & 15.62 & 15.6372 \\
Luas Penampang, mm2 & 191.63 & 192.0528 \\
Beban Leleh, KN & 91.13 & 62.3412 \\
Beban Tarik Maks, KN & 117.53 & 97.0707 \\
Kekuatan Leleh, N/mm2 & 475.58 & 324.5365 \\
kekuatan Tarik Maks, N/mm2 & 613.33 & 505.4552 \\
Regangan kondisi leleh, \% & 0.0023 & 0.0016 \\
Modulus Elastisitas (MPa) & 203036.7697 & 200369.1598 \\
\hline
\end{tabular}

Tujuan penelitian ini untuk mengetahui kapasitas memikul momen pada balok beton bertulang berongga akibat perbedaan kuat Tarik tulanga. efektifitas volume rongga terhadap kinerja balok beton bertulang yang menggunakan tulangan yang berbed dan perbandingan hubungan beban -lendutan pada balpk beton bertulang rongga dengan perbedaan kuat Tarik tulangan. 
B. METODE PENELITIAN

\section{Dimensi Benda Uji Balok}

Dimensi Balok dalam penelitian adalah : Lebar balok : $b=150 \mathrm{~mm}$; tinggi balok : $\mathrm{h}=350 \mathrm{~mm}$; tinggi efektif : $\mathrm{d}=$ 307,5 mm. Tulangan tarik $3 \mathrm{D} 16 \mathrm{~mm}$ dengan 2 variasi kuat tarik, yakni fy : 475 MPa (type WS) dan fy : $325 \mathrm{MPa}$. (Type RM). Tulangan bagi : $2 \phi 8 \mathrm{~mm}$. Tulangan sengkang, di tumpuan : $\phi$ 8-100 dan di lapangan $\phi 8-150 \mathrm{~mm}$ Panjang balok : $\mathrm{L}=$ $3300 \mathrm{~mm}$ ( bentang bebas : $3000 \mathrm{~mm}$ ). Mutu beton f'c : $27 \mathrm{MPa}$, Pada bagian tarik dibawah garis netral dipasang lapisan bekas kemasan botol minuman plastik dengan tinggi 3 lapis botol dan panjang yang bervarias.

\section{Desain Penelitian}

Perhitungan kapasitas balok beton bertulang dalam memikul momen lentur dilakukan melalui digram tegangan whitney sebagaimana Gambar 6 . Sedangkan proses perhitungan kapasitas beban yang dapat dipikul oleh penampang dapat dilihat pada Tabel 2.

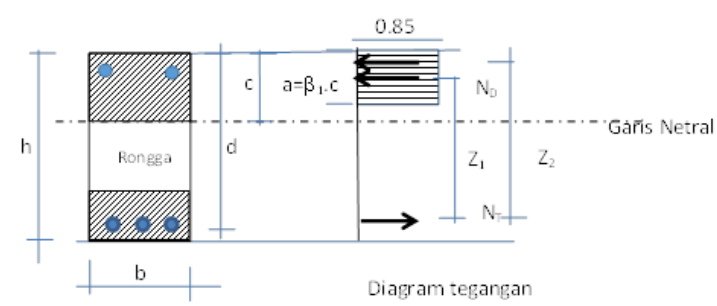

Gambar 6. Diagram Tegangan Whitney
Tabel 2. Perhitungan Kapasitas balok normal

\begin{tabular}{|c|c|c|c|c|}
\hline \multicolumn{3}{|c|}{ URAIAN } & \multicolumn{2}{|c|}{ JENIS BESI TULANGAN } \\
\hline \multicolumn{2}{|r|}{ URAIAN } & \multirow{2}{*}{$\begin{array}{c}\text { SATUAN } \\
\mathrm{mm}\end{array}$} & \multirow{2}{*}{$\begin{array}{c}\text { WS } 16 \\
65.90\end{array}$} & \multirow{2}{*}{$\begin{array}{c}\text { MR } 16 \\
45.09\end{array}$} \\
\hline a & Tinggi blok tegangan tekan ek ivalen & & & \\
\hline c & Tinggi garis netral & $\mathrm{mm}$ & 77.53 & 53.05 \\
\hline $\mathrm{Z} 1$ & jarak titik berat pasangan baja - Beton & $\mathrm{mm}$ & 291.05 & 301.46 \\
\hline $\mathrm{Cc}=$ & Gaya tekan beton $=0.85 \mathrm{f}^{\prime} \mathrm{c}$. a.b. & $\mathrm{N}$ & 225593.51 & 154358.47 \\
\hline $\mathrm{Z} 2$ & jarak titik berat pasangan baja - baja & $\mathrm{mm}$ & 292.00 & 292.00 \\
\hline $\mathrm{Ts}=$ & Gaya tarik baja tekan $\mathrm{Cs}=\mathrm{As}_{2}$. fy & $\mathrm{mm}$ & 47810.06 & 32625.97 \\
\hline \multirow[t]{2}{*}{ Z } & jarak titik berat Gaya tarik dan tekan & $\mathrm{mm}$ & 291.22 & 299.81 \\
\hline & Tinggi Rongga $\max =\mathrm{d}-80-\mathrm{c}$ & $\mathrm{mm}$ & 192.47 & 216.95 \\
\hline \multirow{2}{*}{$\mathrm{Mn}=$} & \multirow{2}{*}{ Momen ultimate $=$ Cc. $Z_{1}+$ Ts. $Z_{2}$} & $\mathrm{Nmm}$ & 79619755.33 & 56058950.04 \\
\hline & & $\mathrm{kNm}$ & 79.62 & 56.06 \\
\hline$P$ & Beban batas $=(\mathrm{Mn}-1.4033) / 0.6$ & $\mathrm{kN}$ & 130.36 & 91.09 \\
\hline
\end{tabular}

\section{Variabel dan Notasi sample}

Nilai variable dan notasi sampel dapat dilihat apda Tabel 3 dibawah ini

Tabel 3. Notasi Benda Uji

\begin{tabular}{|c|c|c|c|c|c|}
\hline NO & $\begin{array}{l}\text { Panjang } \\
\text { Rongga }\end{array}$ & Tinggi rongga & $\begin{array}{c}\text { Kuat Tarik } \\
\text { baja }\end{array}$ & Notasi Benda Uji & $\begin{array}{l}\text { Jumlah } \\
\text { Sampel }\end{array}$ \\
\hline \multirow[b]{2}{*}{1} & \multirow{2}{*}{$\begin{array}{c}4 \text { botol } \\
(880 \mathrm{~mm})\end{array}$} & \multirow{2}{*}{$\begin{array}{l}3 \text { lapis (180 } \\
\mathrm{mm})\end{array}$} & 475 & BR1A WS & 1 \\
\hline & & & 324 & BR1A RM & 1 \\
\hline \multirow[b]{2}{*}{2} & \multirow{2}{*}{$\begin{array}{c}8 \text { botol } \\
(1760 \mathrm{~mm})\end{array}$} & \multirow{2}{*}{$\begin{array}{c}3 \text { lapis (180 } \\
\mathrm{mm})\end{array}$} & 475 & BR2A WS & 1 \\
\hline & & & 324 & BR2A RM & 1 \\
\hline \multirow[b]{2}{*}{3} & \multirow{2}{*}{$\begin{array}{c}12 \text { botol } \\
(2640 \mathrm{~mm})\end{array}$} & \multirow{2}{*}{$\begin{array}{c}3 \text { lapis (180 } \\
\mathrm{mm})\end{array}$} & 475 & BR3A WS & 1 \\
\hline & & & 324 & BR3A RM & 1 \\
\hline
\end{tabular}

\section{Sketsa Benda Uji}

Sktrsa benda uji dapat dilihat apda Gambar 7 dibawah ini.
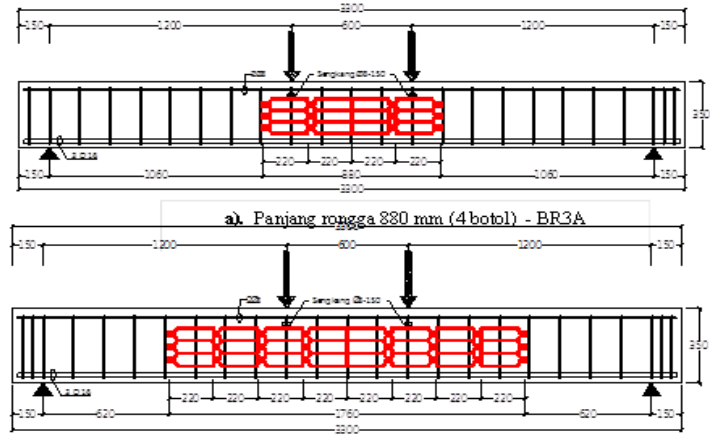

b) Parjang rongga $1760 \mathrm{mun}$ ( 8 botol) - BR3B

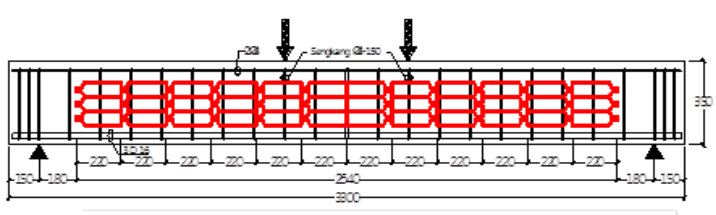

c) Panjang nongga $2640 \mathrm{~mm}$ (12 botol) $-\mathrm{BR} 3 \mathrm{C}$

Gambar 7. Sketsa Variasi rongga 


\section{Pembuatan Benda Uji}

Pengecoran dimulai dari dasar balok uji dan dihentikan pada tinggi $70 \mathrm{~mm}$. Setelah itu botol plastik ditempatkan pada permukaan beton, sesuai dengan variasi tinggi dan panjang yang telah ditetapkan. Pengecoran kemudian dilanjutkan sampai bekisting penuh. Semua balok uji dirawat selama 28 hari sebelum dilakukan pengujian lentur.

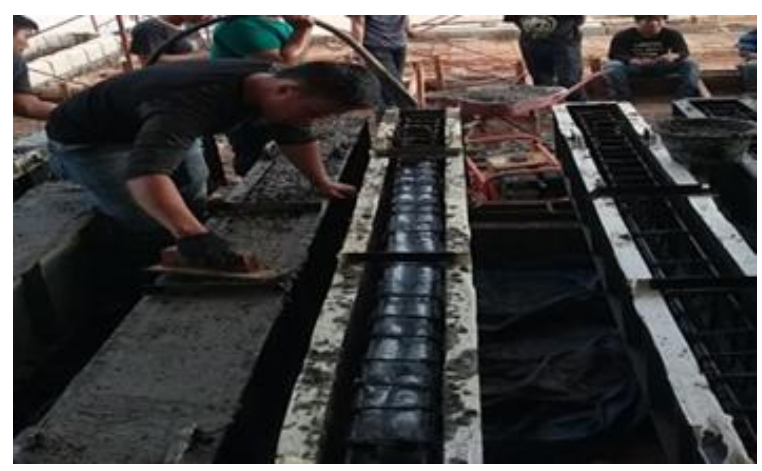

Gambar 8. Pengecoran Benda Uji

\section{Set Up Pengujian}

Beberapa alat pengukur regangan (strain gauges) ditempatkan pada tulangan memanjang dan tulangan geser. Strain gauge juga ditmpatkan pada permukaan beton. Strain gauge digunakan untuk mengukur regangan baja dan beton. Lokas penempatan strain gauge diperlihatkan pada Gambar 9

Gambar 10 menunjukkan pengaturan pembebanan benda uji. Semua balok diuji dengan 4 titik pembebanan menggunakan aktuator dengan beban maksimum 1500 kN. Suatu load cell dengan kapasitas 200
$\mathrm{kN}$ capacity digunakan untuk mengukur besarnya beban. Pemberian beban dilakukan $2 \mathrm{kN}$ per step sampai terjadi retak pertama pada beton, pemberian beban selanjutnya dilakukuan dengan $5 \mathrm{kN}$ per step sampai beban maksimum. Tiga buah LVDT (Linear Variable Displacement Transducer ) digunakan untuk mengukur lendutan balok. Dua LVDT ditempatkan dibawah titik pembebanan, dan satu LVDT ditempatkan pada titik ditengah bentang. Semua data dicatat secara otomatis menggunakan data logger.

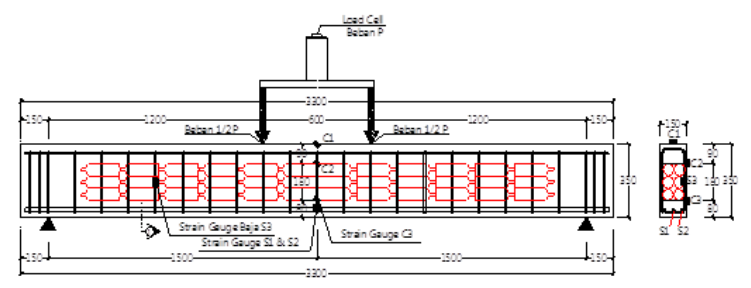

Gambar 9 Penempatan Strain Gauge
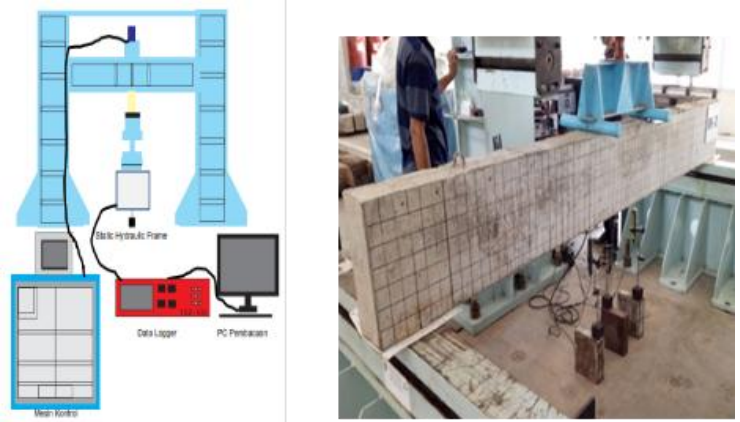

Gambar 10 Setup Pengujian

\section{HASIL DAN PEMBAHASAN}

\section{Beban dan Momen Lentur}

Hasil penelitian mengenai bebdan dan momen lentur dapat dilihat pada Tabel 4. dimana menunjukkan data beban dan lendutan pada kondisi retak awal, pada saat 
tulangan leleh dan pada kondisi beban ultimate, untuk setiap variasi panjang rongga dan perbedaan kuat tarik leleh tulangan.

Tabel 4. Data Kapasitas Lentur

\begin{tabular}{cccc}
\hline \multirow{2}{*}{ Specimen } & $\begin{array}{c}\text { Kode } \\
\text { Tulangan } \\
\text { Balok }\end{array}$ & $\begin{array}{c}\text { Beban } \\
\text { Ultimate. }\end{array}$ & $\begin{array}{c}\text { Momen } \\
\text { Ultimate. }\end{array}$ \\
\cline { 2 - 4 } & Pu $(\mathrm{kN})$ & Mn $(\mathrm{kN}) \mathrm{m}$ \\
\hline \multirow{2}{*}{ BR3A } & $\mathrm{WS}$ & 137.28 & 83.7713 \\
\cline { 2 - 4 } & $\mathrm{RM}$ & 105.77 & 64.8653 \\
\hline \multirow{2}{*}{ BR3B } & $\mathrm{WS}$ & 135.54 & 82.7273 \\
\cline { 2 - 4 } & $\mathrm{RM}$ & 102.96 & 63.1793 \\
\hline \multirow{2}{*}{ BR3C } & $\mathrm{WS}$ & 136.81 & 83.4893 \\
\cline { 2 - 4 } & $\mathrm{RM}$ & 107.09 & 65.6573 \\
\hline
\end{tabular}

Hasil penelitian menunjukkan bahwa kapasitas memikul beban lentur, tidak dipengaruh oleh adanya rongga pada balok dengan tulangan WS dan balok Tulangan MR. Perbedaan kapasitas memikul beban dan momen lentur diakibatkan oleh adanya perbedaan kuat Tarik tulangan. Perbandingan kapasitas memikul beban dan lendutan juga dapat dilihat pada Gambar 11



\section{Ratio Momen Dan Berat Balok}

Ratio kapasitas momen dan berat balok beton bertulang menunjukkan tingkat efisiensi balok. Semakin besar Ratio momen dan berat balok berarti semakin efisien balok tersebut. Tabel 5 dan Gambar 12 memperlihatkan Ratio momen dan berat balok untuk setiap jenis balok berongga dengan perbedaan jenis tulangan

Tabel 5. Ratio Momen dn Berat Balok

\begin{tabular}{ccccc}
\hline \multirow{2}{*}{ specimen } & $\begin{array}{c}\text { Kode } \\
\text { Tulangan } \\
\text { Balok }\end{array}$ & $\begin{array}{c}\text { Berat } \\
\text { W }\end{array}$ & $\begin{array}{c}\text { Momen } \\
\mathrm{Mu}\end{array}$ & $\begin{array}{c}\text { Ratio } \\
\mathrm{Mu} / \mathrm{W}\end{array}$ \\
\cline { 3 - 5 } BR3A & $\mathrm{WS}$ & 3.7540 & 83.7713 & 22.32 \\
\cline { 2 - 5 } & $\mathrm{RM}$ & 3.7572 & 64.8653 & 17.26 \\
\hline \multirow{2}{*}{ BR3B } & $\mathrm{WS}$ & 3.4254 & 82.7273 & 24.15 \\
\cline { 2 - 5 } & $\mathrm{RM}$ & 3.4335 & 63.1793 & 18.40 \\
\hline \multirow{2}{*}{ BR3C } & $\mathrm{WS}$ & 3.0198 & 83.4893 & 27.65 \\
\cline { 2 - 5 } & $\mathrm{RM}$ & 3.0068 & 65.6573 & 21.84 \\
\hline
\end{tabular}

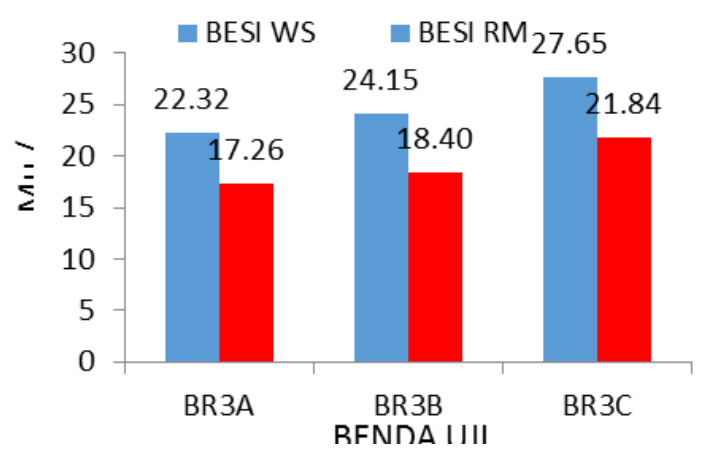

Gambar 12. Grafik Ratio Momen Ultimate Vs Berat Balok

Gambar 12 menunjukkan bahwa ratio momen -berat balok cenderung meningkat. Pada balok BR3C WS meningkat $23.9 \%$ terhadap balok BR3A WS. Sedangkan pada balok bertulangan baja BR3C RM meningkat $26,5 \%$. terhadap ratio momen berat balok BR3A RM.

\section{Hubungan Beban dan Lendutan}

Hubungan beban dan lendutan dibagi atas 3 phase, yakni kondisi retak awal, kondisi tulangan Tarik leleh dan kondisi 
beban ultimate. Hasil pengujian dapat dilihat pada Tabel 6 yang kemudian dibuat grafiknya dalam Gambar 13. Pada kondisi retak awal, nilai beban pada semua specimen menunjukkan nilai yang sama. Semua bagian penampang masih dalam kondisi utuh,. Pada kondisi tulangan leleh, terlihat bahwa Kapasitas beban balok rongga bertulangan WS lebih besar dibanding kapasitas balok berongga dengan tulangan RM. sementara lendutan pada balok bertulangan WS cenderung lebih besar dibanding balok bertulangan RM, walaupun perbedaanya tidak terlalu signifikan. Sedangkan pada kondisi beban ultimate balok beton rongga yang menggunakan besi tulangan WS, mempunyai kapasitas beban yang lebih tinggi dibanding dengan balok bertulangan RM. nilainya cukup signifikan yakni ratarata 29,72\%.. Perbedaan yang cukup signifikan justru terjadi akibat perbedaan volume rongga. Terlihat bahwa pada balok BR3B terjadi peningkatan lendutan sebesar $9.5 \%$ dibanding balok BR3A, sedangkan pada balok BR3C, peningkatan lendutan sebesar $55.5 \%$ terhadap balok BR3A.

Tabel 6. Pengujian Beban Lendutan Varian Balok Pada 3 Tahap Pembebanan

\begin{tabular}{cccccccc}
\hline \multirow{2}{*}{ Specimen } & $\begin{array}{c}\text { Kode Tulangan } \\
\text { Balok }\end{array}$ & \multicolumn{2}{c}{ Retak awal } & \multicolumn{2}{c}{ Tulangan Lelah } & \multicolumn{2}{c}{ Beban Ultimate. } \\
\cline { 3 - 9 } & & Pcr $(\mathrm{kN})$ & $\Delta \mathrm{cr}(\mathrm{mm})$ & $\mathrm{Py}(\mathrm{kN})$ & $\Delta \mathrm{y}(\mathrm{mm})$ & $\mathrm{Pu}(\mathrm{kN})$ & $\Delta \mathrm{u}(\mathrm{mm})$ \\
\hline \multirow{2}{*}{ BR3A } & WS & 12.93 & 0.41 & 120.62 & 12.59 & 137.28 & 22.09 \\
\cline { 2 - 8 } & RM & 12.60 & 0.81 & 88.03 & 9.955 & 105.77 & 20.56 \\
\hline \multirow{2}{*}{ BR3B } & WS & 9.56 & 0.5 & 116.62 & 13.26 & 135.54 & 22.31 \\
\cline { 2 - 8 } & RM & 11.26 & 1.105 & 97.36 & 10.8 & 102.96 & 24.37 \\
\hline \multirow{2}{*}{ BR3C } & WS & 10.2 & 0.49 & 114.89 & 13.34 & 136.81 & 30.94 \\
\cline { 2 - 8 } & RM & 11.06 & 0.82 & 95.56 & 11.02 & 107.09 & 35.39 \\
\hline
\end{tabular}

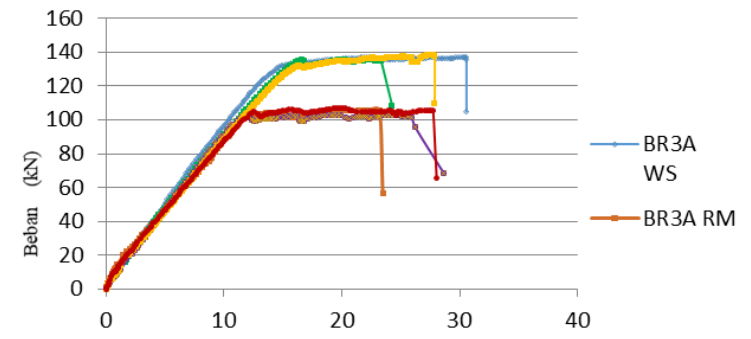

Gambar 13. Hubungan Beban Lendutan Balok Bertulangan WS dan MR

\section{KESIMPULAN DAN SARAN}

Hasil penelitian dan pembahasan dapat ditarik kesimpulan bahwa perbedaan kemampuan memikul beban dan momen lentur pada semua varian rongga diakibatkan oleh perbedaan kuat tarik Baja tulangan Tipe WS dan tipe RM. Hasil penelitian menunjukkan bahwa efisiensi balok BR3C lebih baik dibanding balok BR3A dan BR3B, baik pada balok yang menggunakan tulangan type WS maupun pada balok bertulang tipe RM. Perbedaan kuantitas rongga tidak mempengaruhi kemampuan balok memikul beban baik pada kondisi retak, kondisi tulangan leleh maupun pada saat beban ultimate. Perbedaan signifikan justru terjadi pada lendutan, Balok dengan rongga terpanjang menunjukkan nilai lendutan yang paling besar.

\section{DAFTAR PUSTAKA}

Dhinesh.N.P, and Satheesh. S.V. (2017), "Flexural Behaviour of Hollow Square Beam, IJSEAS, Volume-3, Issue-3, March 2017, pp. 236 - 242. 
Djamaluddin, R, (2013), “Flexural Behaviour of External Reinforced Concrete Beams", Proceedings of the 2nd ICRMCE, Sebelas Maret Univ 2013.

Irmawaty, R., Djamaluddin, R, Malim, Wa O. A. R, (2016), "Flexural Behavior Of Styrofoam-Filled Concrete, IJEsCA, vol. 3, 1, May 2016, hal. 9 - 14.

Joy, J , Rajeev, R. (2014), "Effect of Reinforced Concrete Beam with Hollow Neutral Axis", IJSRD, Vol. 2, Issue 10, 2014. pp. $341-348$

Kumar,A.S, Joy, A (2015) "Experimental Investigation on Partial Replacement of Concrete Below Neutral Axis of Beam", IJSR, Vol. 4-- 8, Aug 2015, pp1670 1674.

Mathew, I and Varghese S.M, (2016), "Experimental Study on Partial Replacement of Concrete in and Below Neutral Axis of Beam", IJIRT, Volume 3 Issue 4, September 2016, pp.188 - 192

Park, R \& Paulay, T. (1975), Reinforced concrete Structures, A Willey Interscience Publication, John Willey \& Sons, New York

Parthiban, $\mathrm{N}$ and Neelamegam, M (2017), "Flexural Behavior Of RC Beam With Hollow Core In Shear Section, IRJET, Volume: 04 Issue: 04 April -2017, pp, 2263 2274

Rahardyanto,(2013),“Studi eksperimen tal balok berongga dengan limbah botol PET", Jurnal Penelitian FT UI.

Sariman, S, and Nurdin, A.R, (2018), "Flexural Behaviour of T-Shaped RC Hollow Beam with Plastic Bottle Waste", IJCIET,Vol.9, Issue4, Apr.'18, pp.534-543,

Syahrul Sariman, Herman Parung, Rudy Djamaluddin dan Rita Irmawaty, (2020) "Flexural charachteristic of
RC Beam with hollow core variation in Tension Area" Journal of Engineering \& Applied Science (JEAS), ISSN 1816-949X, Vol. 15 Issue 6, January 2020, pp 1537 1543, Medwell Publications,

Varghese, A Basil. M.J, (2016), "Experimental and Numerical Studies on Reinforced Concrete Hollowcore Sandwich Beams", IJIRSET, Vol. 5, Issue 8, August 2016, pp.14730 - 14737.

Varghese, N, Joy.A, (2016), Flexural Behaviour of RC Beam with Hollow Core at Various Depth, IJSR, Volume 5 Issue 5, May 2016, pp. $741-746$. 